\title{
A Possible Role for HSV-1-Specific Humoral Response and PILRA rs1859788 Polymorphism in the Pathogenesis of Parkinson's Disease
}

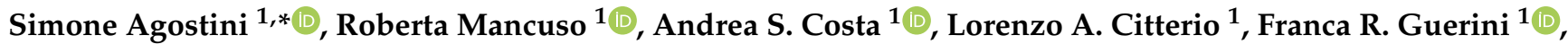 \\ Mario Meloni ${ }^{1}$, Jorge Navarro ${ }^{1}$ and Mario Clerici ${ }^{1,2}$ (D) \\ 1 IRCCS Fondazione Don Carlo Gnocchi ONLUS, 20148 Milan, Italy; rmancuso@dongnocchi.it (R.M.); \\ acosta@dongnocchi.it (A.S.C.); lcitterio@dongnocchi.it (L.A.C.); fguerini@dongnocchi.it (F.R.G.); \\ mmeloni@dongnocchi.it (M.M.); jnavarro@dongnocchi.it (J.N.); mario.clerici@unimi.it (M.C.) \\ 2 Department of Pathophysiology and Transplantation, University of Milan, 20122 Milan, Italy \\ * Correspondence: sagostini@dongnocchi.it
}

check for updates

Citation: Agostini, S.; Mancuso, R.; Costa, A.S.; Citterio, L.A.; Guerini, F.R.; Meloni, M.; Navarro, J.; Clerici, M. A Possible Role for HSV-1-Specific Humoral Response and PILRA rs1859788 Polymorphism in the Pathogenesis of Parkinson's Disease. Vaccines 2021, 9, 686. https:// doi.org/10.3390/vaccines9070686

Academic Editor: Ralph A. Tripp

Received: 11 May 2021

Accepted: 17 June 2021

Published: 22 June 2021

Publisher's Note: MDPI stays neutral with regard to jurisdictional claims in published maps and institutional affiliations.

Copyright: (C) 2021 by the authors. Licensee MDPI, Basel, Switzerland. This article is an open access article distributed under the terms and conditions of the Creative Commons Attribution (CC BY) license (https:// creativecommons.org/licenses/by/ $4.0 /)$.

\begin{abstract}
The etiology of Parkinson's disease (PD), a progressive nervous system disorder that affects movement, is still unknown; both genetic and environmental factor are believed to be involved in onset of the disease and its development. Herpes simplex virus type 1 (HSV-1), in particular, is suspected to have a role in PD. Paired Immunoglobulin-like type 2 receptor alpha (PILRA) is an inhibitory receptor that down-regulates inflammation and is expressed on innate immune cells. The PILRA rs1859788 polymorphism is protective against Alzheimer's disease, even in relation with HSV-1 antibody titers, but no data are available in PD. We analyzed HSV-1 antibody titers and PILRA rs1859788 in PD $(n=51)$ and age-and sex-matched healthy controls (HC; $n=73)$. Results showed that HSV-1, but not cytomegalovirus (CMV) or human herpes virus type 6 (HHV-6) antibody titers were significantly higher in PD compared to HC ( $p=0.045)$. The rs1859788 polymorphism was not differentially distributed between $\mathrm{PD}$ and $\mathrm{HC}$, but the minor allele A was more frequently carried by PD $(68 \%)$ compared to HC $(50 \%)(p=0.06)$. Notably, the rs 1859788 minor allele A was statically more frequent in male PD $(65 \%)$ compared to male HC $(37 \%)(p=0.036)$. Finally, no relation was found between HSV-1 antibody titers and PILRA genotype. Results herein suggest an involvement of HSV-1 in PD and indicate a possible interaction between PILRA gene polymorphisms and this neuropathology.
\end{abstract}

Keywords: Parkinson's disease; HSV-1; paired immunoglobulin-like type 2 receptor alpha; antibody titers; rehabilitation

\section{Introduction}

Parkinson's disease (PD), one of the most common neurodegenerative conditions, affects about $2 \%$ of older individuals and about 6 million individuals worldwide, and is a progressive nervous system disorder that impairs movement [1]. The most common PD symptoms are resting tremors, unstable posture, bradykinesia, rigidity, and non-motor symptoms, such as dysphagia [2]. PD is characterized by the loss of neurons in the substantia nigra, possibly resulting from the accumulation of misfolded and aggregated forms of $\alpha$-synuclein protein within Lewy bodies [3,4]. $\alpha$-synuclein is a 140 aa protein located at presynaptic terminals. Its exact role is not completely clear, but it seems that can regulate the amount of SNARE complex, which regulates the neurotransmitters release [5].

Microglia-driven chronic neuroinflammation, oxidative stress, autophagy disruption, and mitochondrial dysfunction are typical features of the pathology $[1,6,7]$.

Currently there is no cure for the disease, but dopaminergic therapies as levodopa and dopamine agonists are commonly used for the control of motor symptoms.

The etiology of PD is still unknown, but epidemiological studies suggest a strong association between genetics and environmental factors in the onset and development of 
the disease [8]. Thus, several viruses have been associated with the disease: influenza A, measles, hepatitis $C$ virus, and herpesviruses [9-11].

A possible role for viral infections in the development of PD was initially proposed by Von Economo [12]. This researcher observed that the lethargic encephalitis, appearing as a complication of the Spanish Flu pandemic of 1918, was associated with brain inflammatory lesions in the midbrain tegmentum and the substantia nigra. Although the mechanistic link between influenza and PD remains enigmatic and controversial, mouse model showed that highly pathogenic strain $\mathrm{H} 5 \mathrm{~N} 1$ influenza can reach the brain and initiate central nervous system (CNS) disorders of protein aggregation including Parkinson's and Alzheimer's diseases [13].

Among herpesviruses, in particular, human herpes simplex virus type 1 (HSV-1) is strongly suspected to have a role in the disease. Thus, high HSV-1-specific antibody titers and a more frequent incidence of HSV-1 infections were observed in patients with idiopathic PD [14-18], although these findings were not always confirmed [19].

HSV-1 is a double-stranded DNA virus that belongs to the Alphaherpesvirinae subfamily and commonly infects humans [20]. After the primary infection, usually occurring before adulthood, HSV-1 can establish latency in sensory ganglia; over time viral reactivations are observed, but they are controlled by the host immune response [21]. HSV-1 is a highly prevalent infection worldwide, as about the $67 \%$ of the population under the age of 50 was shown to be infected [22]. Some results suggest that if the equilibrium between viral reactivation and host immune response is lost, excessive HSV-1 replication, together with neuroinflammation become key factors in the pathogenesis of PD [23-25]. This hypothesis fits within the dual-hit theory for PD, which postulates that the initial event of the disease is a pathogenic access of viruses into the brain through the stomach and the nose [26]: the observation that HSV-1 can establish life-long persistence in the olfactory bulb reinforces a possible pathogenic role for this virus in PD [27,28].

HSV-1 in not suggested to only be involved in PD, but is also suspected to participate to the pathogenesis of Alzheimer's disease (AD). Thus: (1) HSV-1 specific IgG titers and avidity are higher in AD patients compared to healthy controls [29,30]; (2) HSV-1 antibody avidity associates with $\mathrm{AD}$ conversion in individuals with mild cognitive impairment (MCI) [31]; (3) HSV-1 specific IgG titers positively correlate with brain grey matter volumes and cortical thinning in AD patients [30,32]; (4) in vitro and animal studies showed that HSV-1 can cause accumulation of amyloid-beta and hyperphosphorylated tau, key factors of the disease [33-35]; (5) an in vitro study on human neural cells showed that HSV-1 directly impairs autophagy, reducing amyloid-beta degradation [36].

Among herpesviruses, even cytomegalovirus (CMV) was suspected to have a role in PD [37], at least in association with other viral or bacterial infection [38], whereas for the neurotropic human herpes virus 6 (HHV-6), to our knowledge, in scientific literature, just a case report presented a possible relation with Parkinsonism symptoms [39].

As is the case for PD, the pathogenesis of $\mathrm{AD}$ includes the presence of barely identified genetic factors as well; one of these factors is the polymorphisms of paired Immunoglobulinlike type 2 receptor alpha (PILRA), an inhibitory receptor expressed on innate immune cells that down-regulates inflammation $[40,41]$. The human PILRA gene, with a length of 32,567 nucleotides, is located on chromosome 7 (7q22.1), and coded for a 303 amino acids (aa) protein, characterized by 3 different domains: an extracellular domain (178 aa), a transmembrane domain (21 aa), and a cytoplasmatic domain (85 aa). The gene includes a number of single nucleotide polymorphisms (SNP), amongst them the rs1859788 causes an A-to-G transition, and a consequent Arginine (R)-to-Glycin $(\mathrm{G})$ substitution at 78 amino acid (aa).

This SNP was shown to be an AD risk locus [42], and recently it was demonstrated that the presence of Arginine at 78 aa (R78) is protective against AD development [43]. PILRA plays a key role in HSV-1 infection, as the virus binds this protein to infect cells [44]. Notably, the PILRA R78 SNP reduces viral infectivity; as a consequence, R78/R78 people are less susceptible to HSV-1 infection and, in case of infection, HSV-1 recurrence and 
reactivation are greatly reduced [43]. These results were further confirmed by recent data indicating the presence of a correlation between the PILRA rs1859788 polymorphism and HSV-1 specific IgG titers in AD [45].

Starting from this background, we verified these parameters in PD patients in the attempt to shed light on the pathogenesis of this disease.

\section{Materials and Methods}

\subsection{Patients and Controls}

A total of 124 individuals were included in the study: 51 (15 male and 36 female) patients with a diagnosis of Parkinson's disease (PD) and 73 (32 male and 41 female) age-and sex-matched healthy controls (HC). All subjects were recruited by the IRCCS Santa Maria Nascente, Don Gnocchi Foundation, Milan, Italy and were enrolled in rehabilitation programs. Patients were diagnosed as being affected by PD by clinical evaluation, according to the Movement Disorder Society (MDS) Clinical Diagnostic Criteria for PD [46]. Disease severity, based on the Modified Hoehn and Yahr (H\&Y) stage and MDS-Unified Parkinson's Disease Rating Scale-III (MDS-UPDRS-III) scores [47], as well as dopaminergic and non-dopaminergic antiparkinsonian therapy were collected for each patient. Levodopa equivalent daily dose (LEDD) was calculated for each patient [48]. The study conformed the ethical principles of the Declaration of Helsinki; all subjects gave informed and written consent according to a protocol approved by the local ethics committee of the Don Carlo Gnocchi Foundation (\#06_21/06/2018). Whole blood and serum samples were collected from all the enrolled subjects.

\subsection{ELISA}

\subsection{1. $\alpha$-Synuclein Measurement}

Soluble $\alpha$-synuclein was measured in plasma of all the enrolled subjects by using a commercial enzyme-linked immunosorbent assay (ELISA), according to the manufacturer's instructions (IBL International, Hamburg, German). Briefly, $100 \mu \mathrm{L}$ of plasma samples diluted (1:2) with sample diluent were transferred into the pre-coated microwells and the plates were incubated overnight at $4{ }^{\circ} \mathrm{C}$. After washing steps with washing buffer, $100 \mu \mathrm{L}$ of labeled antibody were added to each well and incubated for $60 \mathrm{~min}$ at $4{ }^{\circ} \mathrm{C}$. After re-washing step, $100 \mu \mathrm{L}$ of chromogen solution were added to each well and incubated at room temperature for $30 \mathrm{~min}$. Finally, $100 \mu \mathrm{L}$ of stop solution were added to each well and the reaction stopped. The wells were read on a plate reader (Sunrise, Tecan, Mannedorf, Switzerland) and optical densities (OD) of wells were determined at $450 \mathrm{~nm}$. $\alpha$-synuclein concentration was expressed as $\mathrm{ng} / \mathrm{mL}$ (sensitivity: $0.03 \mathrm{ng} / \mathrm{mL}$ ).

\subsubsection{Anti-Herpetic IgG Antibody Measurements}

HSV-1, CMV, and HHV-6 total IgG titers were measured in serum of all the enrolled subjects. The viral IgG titers were used by ELISA (HSV-1 IgG, IBL International, Hamburg, Germany, CMV IgG, Abcam, Cambridge, MA. US, and HHV-6 IgG, Abnova, Taipei, Taiwan) according to standard protocol. Briefly, $100 \mu \mathrm{L}$ of serum samples diluted (1:100 for HSV-1 and CMV, 1:10 for HHV-6) with appropriate sample diluent were transferred into the appropriate viral antigens coated polystyrene microwells and the plates were incubated for 60 min (at room temperature for HHV-6, at $37^{\circ} \mathrm{C}$ for CMV and HSV-1). After washing steps with washing buffer to remove the unbound proteins, $100 \mu \mathrm{L}$ of appropriate peroxidase conjugate was added to each well and incubated for $60 \mathrm{~min}$ for HHV-6, for $30 \mathrm{~min}$ for CMV and HSV-1 (at room temperature for HHV-6 and HSV-1, at $37^{\circ} \mathrm{C}$ for CMV). After re-washing step, $100 \mu \mathrm{L}$ of appropriate chromogen/substrate solution were added to each well and incubated at room temperature for 15 min for HSV-1 and CMV, 20 min for HHV-6. Finally, $100 \mu \mathrm{L}$ of stop solution were added to each well and the reaction stopped. The wells were read on a plate reader (Sunrise, Tecan, Mannedorf, Switzerland) and optical densities (OD) of wells were determined at 450/620 nm. HSV-1 Ab titers are expressed as units (U), HHV-6 Ab titers were expressed as positivity index (PI), and CMV Ab titers 
were expressed as arbitrary units $/ \mathrm{mL}(\mathrm{AU} / \mathrm{mL})$, as indicated by the ELISA kits. For HSV-1, subjects with $\mathrm{U} \geq 5$ were considered seropositive; for $C M V$, subjects with $U / \mathrm{mL} \geq 10$ were considered seropositive; for $\mathrm{HHV}-6$, subjects with $\mathrm{PI} \geq 1.11$ were considered seropositive.

HSV-1 IgG avidity was measured using a protein-denaturing agent, as previously described [31]. Briefly, the protocol used is the protocol for ELISA analysis, with the addition of $6 \mathrm{M}$ urea to the washing solution at the washing step after serum reaction. The avidity index (indicated as \%) was calculated as follows: anti-HSV-1 Ab titer measured with washing including urea/anti-HSV-1 Ab titer measured with washing without urea.

\subsection{PILRA rs1859788 Genotyping}

Genomic DNA was isolated from whole blood by phenol-chloroform extraction for all the enrolled population. Custom-design TaqMan probes were used for the PILRA rs1859788 genotyping, as reported in our previous study [45], using Bio-Rad CFX96 Touch ${ }^{\mathrm{TM}}$ RealTime PCR Detection System (Bio-Rad. Hercules, CA, USA). Primers and probes are: Forward primer: 5'-GCT CCC GAC GTG AGA ATA TCC-3'; Reverse primer: 5'-GCG GCC TTG TGT AGA A-3'; Reporter 1 sequence: HEX 5'-ACT TCC ACG GGC AGT C-3'MGBEQ; Reporter 2 sequence: FAM 5'-ACT TCC ACA GGC AGT C-3'-MGBEQ. The PCR amplification was performed as follows: $2 \mathrm{~min}$ at $50{ }^{\circ} \mathrm{C}, 10 \mathrm{~min}$ at $95^{\circ} \mathrm{C}, 40$ cycles consisting of $15 \mathrm{~s}$ denaturation at $95^{\circ} \mathrm{C}$ and a $60 \mathrm{~s}$ annealing and extension at $60{ }^{\circ} \mathrm{C}$, followed by a hold at $4{ }^{\circ} \mathrm{C}$.

\subsection{Statistical Analysis}

Chi-square goodness of fit test was used to verify that the rs1859788 polymorphism was in Hardy-Weinberg (HW) equilibrium and to evaluate case-control differences of SNP distribution. Normally distributed data were summarized as mean \pm standard deviation, and comparison among groups were analyzed by Student t test. Not-normally distributed data were summarized as median and interquartile range (IQR: 25th and 75th percentile), and comparisons were analyzed by Mann-Whitney U test, as appropriate. Qualitative data were compared using Fisher's exact test and chi-squared test and $p$-value was considered significant when $\leq 0.05$ after Bonferroni correction for 2 degrees of freedom $\left(\mathrm{p}_{\mathrm{c}}\right)$ in $2 \times 3$ and $2 \times 2$ contingency tables. The statistical analyses were accomplished using commercial software (MedCalc Statistical Software version 14.10.2., Ostend, Belgium, and IBM SPSS Statistics 26.0, IBM Inc. Chicago, IL, USA). $p$-values $\leq 0.05$ were considered statistically significant.

\section{Results}

\subsection{Clinical Characterization of the Study Population}

Demographic and clinical characteristic of the individuals enrolled in the study are summarized in Table 1. Briefly, gender and age were comparable between PD and HC; the disease duration of PD patients was $7.4 \pm 5.1$ years and total LEDD was $512.8 \pm 280.8 \mathrm{mg} / \mathrm{die}$ The majority of patients reported anosmia or constipation in the initial stages of the disease.

Table 1. Demographic and clinical characteristics of the individuals enrolled in the study.

\begin{tabular}{ccc}
\hline $\begin{array}{c}\text { Demographic and } \\
\text { Clinical Characteristics }\end{array}$ & PD Patients & Healthy Controls \\
\hline$n$. & 51 & 73 \\
Gender (M:F) & $15: 36$ & $32: 41$ \\
Age, years (mean \pm SD) & $69.5 \pm 8.5$ & $69.5 \pm 8.0$ \\
Disease duration (mean \pm SD) & $7.4 \pm 5.1$ & - \\
MDS-UPDRS III (mean \pm SD) & $27.6 \pm 13.0$ & - \\
Modified H\&Y (median; IQR) & $2.0 ; 1.5-3.0$ & - \\
LEDD, mg/die (mean \pm SD) & $512.8 \pm 280.8$ & $12.25 ; 8.00-20.20$ \\
\hline
\end{tabular}

${ }^{1}$ PD vs. HC: $p=0.0001$. PD: Parkinson's disease; M: male; F: female; n.: absolute number; SD: standard deviation; IQR: Interquartile Range; MDS-UPDRS III: Movement Disorders Society Unified Parkinson's Disease Rating Scale; Modified H\&Y: Modified Hoehn and Yahr scale; LEDD: levodopa equivalent daily dose. 


\subsection{Plasmatic $\alpha$-Synuclein Concentration}

The $\alpha$-synuclein was detected in plasma of all patients and controls. It was, as expected, significantly higher in PD $(19.43 \mathrm{ng} / \mathrm{mL} ; 15.22-23.12 \mathrm{ng} / \mathrm{mL})$ compared to HC $(12.25 \mathrm{ng} / \mathrm{mL} ; 8.00-20.20 \mathrm{ng} / \mathrm{mL} ; p=0.0001)$. No correlation was found between $\alpha$-synuclein concentration and demographic (age and gender) and clinical data (disease duration, MDP-UPDRS III, modified H\&Y, LEDD).

\subsection{Virological Results}

The overall rate of seropositivity was $94 \%$ for HSV-1, $93 \%$ for CMV, and $62 \%$ for HHV-6 (both CMV and HHV-6 were used as controls for HSV-1 seroprevalence). HSV-1 seropositivity was higher in PD (98\%) than HC $(92 \%)$, whereas for the other two herpesviruses an opposite situation was observed as antibodies for both CMV (PD: 88\%; HC: 98\%) and HHV-6 (PD: 56\%; HC: 67\%) were more frequently observed in HC than in PD patients.

HSV-1 antibody titers levels were significantly higher in PD compared to HC $(p=0.045)$ (Figure 1); the HSV-1 avidity index was increased as well, although not significantly, in PD compared to HC. In contrast with these results, no significant difference was observed regarding the antibody titers of CMV and HHV-6 between the two groups. All the virological data are schematized in Table 2. Finally, no correlations were observed among HSV-1, CMV, HHV-6 antibody titers, HSV-1 avidity index, plasmatic $\alpha$-synuclein concentration, and demographic (age and gender) and clinical data (disease duration, MDP-UPDRS III, modified H\&Y, LEDD) (data not shown).

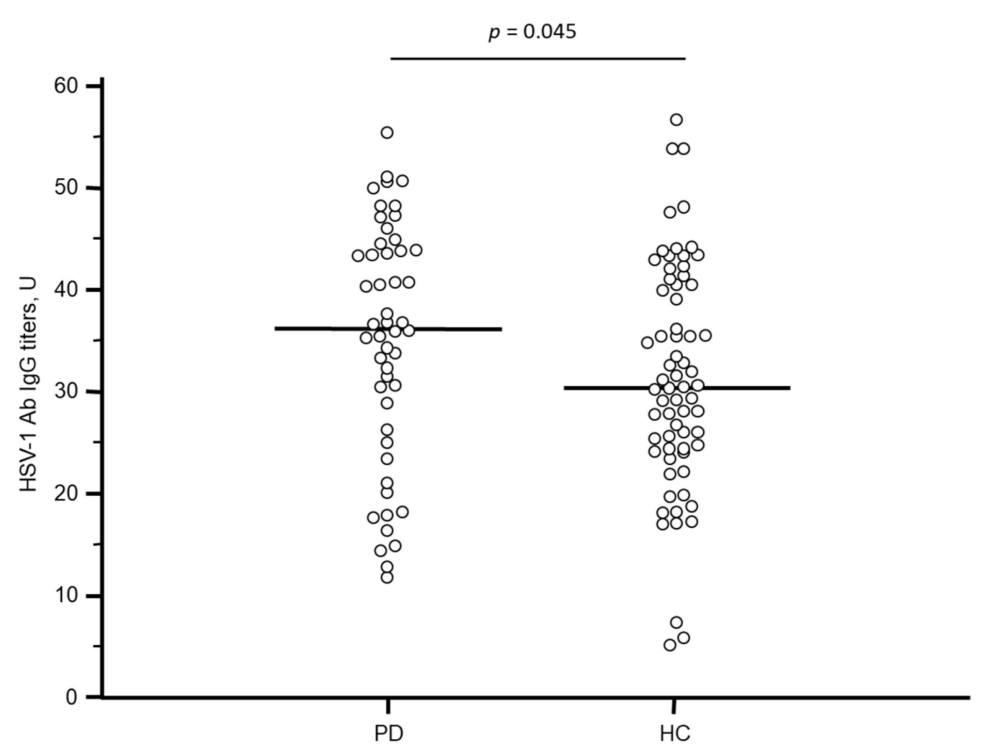

Figure 1. Distribution of serum HSV-1-specific IgG titers in Parkinson's Disease patients and Healthy Controls. Horizontal lines represent the median. PD: Parkinson's Disease; HC: Healthy Controls; U: units.

Table 2. Virological characteristics of the individuals enrolled in the study.

\begin{tabular}{lcc}
\hline \multicolumn{1}{c}{ Virological Characteristics } & PD Patients & Healthy Controls \\
\hline HSV-1 seropositivity, \% & 98 & 92 \\
HSV-1 IgG, U (median; IQR) & $36.2 ; 32.8-40.6^{1}$ & $30.3 ; 27.7-34.7$ \\
HSV-1 avidity index, \% (median; IQR) & $92.1 ; 83.4-97.5$ & $88.6 ; 83.8-91.8$ \\
CMV seropositivity, \% & 88 & 98 \\
CMV IgG, AU / mL (median; IQR) & $161.2 ; 141.7-196.9$ & $193.5 ; 159.0-221.2$ \\
HHV-6 seropositivity, \% & 56 & 67 \\
HHV-6, P.I. (median; IQR) & $5.4 ; 1.7-2.5$ & $2.6 ; 2.0-3.3$ \\
\hline
\end{tabular}

${ }^{1}$ PD vs. HC: $p=0.045$. PD: Parkinson's disease; IQR: Interquartile Range; U: units; AU/mL: arbitrary unit/mL; P.I.: positivity index; HSV-1: herpes simplex virus type 1; CMV: cytomegalovirus; HHV-6: human herpesvirus type 6; IgG: immunoglobulin G. 


\subsection{PILRA rs1859788 Genotyping}

The genotype distribution of PILRA (A/G) rs1859788 polymorphism was in HardyWeinberg (HW) equilibrium both in PD and HC groups. Although PILRA rs1859788 was not differentially distributed between PD and HC, a trend of significance $(p=0.06)$ was found regarding the minor allele $\mathrm{A}(\mathrm{AA}+\mathrm{AG})$, that was more frequently carried by $\mathrm{PD}$ (67.3\%) compared to HC (50\%) (Table 3$)$.

Table 3. Genotype and allelic distribution of PILRA rs1859788 polymorphism in the individuals enrolled in the study.

\begin{tabular}{cccccccc}
\hline Groups & \multicolumn{3}{c}{ PILRA rs1859788 } & \multicolumn{2}{c}{ PILRA rs1859788 } & \multicolumn{2}{c}{ PILRA rs1859788 } \\
\hline Genotype/Allele & A G & A G & G G & A (A + AG) & G G & A & G \\
\hline PD, \% & 16.3 & 51.0 & 32.7 & 67.3 & 32.7 & 41.8 & 58.2 \\
HC, \% & 12.5 & 37.5 & 50.0 & 50.0 & 50.0 & 31.3 & 68.7 \\
\hline Men & & & & & & & \\
PD, \% 1 & 17.7 & 47.0 & 35.3 & 64.72 & 35.3 & 41.2 & 58.8 \\
HC, \% & 18.5 & 18.5 & 63.0 & 37.1 & 62.9 & 27.8 & 72.2 \\
\hline Women & & & & & & & \\
PD, \% & 13.3 & 60.0 & 26.7 & 73.3 & 26.7 & 43.3 & 56.7 \\
HC, \% & 8.1 & 51.4 & 40.5 & 59.5 & 40.5 & 33.8 & 66.2 \\
\hline
\end{tabular}

${ }^{1}$ PD vs. $\mathrm{HC}: \mathrm{p}_{\mathrm{c}}=0.05 ;$ d.f.: $2 ; \mathrm{Chi}^{2}=5.99 .{ }^{2}$ PD vs. $\mathrm{HC}: \mathrm{p}_{\mathrm{c}}=0.0036 ;$ OR: $3.056 ; 95 \% \mathrm{CI}=1.07-9.09$. PD: Parkinson's disease; HC: Healthy Controls; PILRA: paired immunoglobulin-like type 2 receptor alpha; d.f.: degrees of freedom; OR: odd ratio; CI: confidence interval.

Moreover, when the study population was split in relation with gender, the rs 1859788 genotypes distribution was statistically different in male PD compared to male $\mathrm{HC}\left(p_{\mathrm{c}}=0.05\right.$; d.f.: $\left.2 ; \chi^{2}=5.99\right)$, with, again, the minor allele $\mathrm{A}(\mathrm{AA}+\mathrm{AG})$ being statically more frequent in male PD (64.7\%) compared to male HC (37.1\%) ( $p_{\mathrm{c}}=0.036$; OR: 3.056; 95\% CI: 1.07-9.09) (Table 3). No relations were observed among PILRA genotype and HSV-1 (Figure 2), CMV and HHV- 6 titers, HSV- 1 avidity index and plasmatic $\alpha$-synuclein concentration (data not shown).

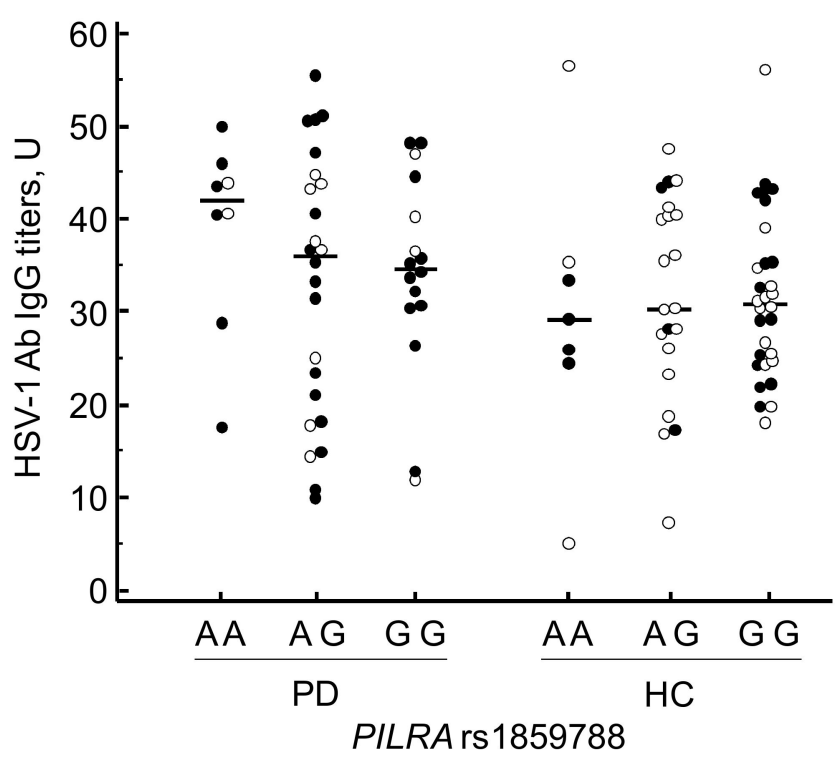

Figure 2. Distribution of serum HSV-1-specific IgG titers in Parkinson's Disease patients and Healthy Controls according to PILRA rs2859788 genotypes and gender. Black dots: male; white dots: female. Horizontal lines represent the median. PD: Parkinson's Disease; HC: Healthy Controls; U: units. 


\section{Discussion}

The pathogenesis of PD is only barely understood. Among several factors-host immune system, host genetics, environmental factors-pathogens are suspected to have a possible role in the disease. Among pathogens, HSV-1, in particular is strongly suspected to be associated with the disease.

Here we show that higher HSV-1-specific antibody titers are seen in PD patients compared to HC, and that this is specific for HSV-1, as the antibody titers against other neurotropic viruses, including, CMV and HHV-6, another neurotropic herpesvirus, were similar in PD and HC. How HSV-1 may contribute to the disease is not understood. One hypothesis is that HSV-1 could alter the host innate immunity, and, in particular, could impair the INF- $\beta$-mediated immune response [49]. Although an altered immune response has not been associated with the initial events that lead to PD, an alteration in the production of pro-inflammatory cytokines was repeatedly shown to facilitate disease progression through the involvement of microglia and astrocytes.

Parkinson's disease was recently hypothesized to be an autoimmune disease, or at least a disease with features typical of autoimmunity [50,51]. This idea stems from the observation that the accumulation of misfolded and aggregated forms of $\alpha$-synuclein can activate the adaptive immune response [52,53].

HSV-1 could also have a role in triggering autoimmunity in $\mathrm{PD}$, as regions of molecular mimicry that could result in the stimulation of an immunologic cross-reactivity between HSV-1 and human $\alpha$-synuclein do exists [23]. In this regard it is interesting to underline that both $\alpha$-synuclein ${ }_{100-114}$ and HSV-1 UL4222-36 peptides can stimulate in vitro cell-mediated immune responses by peripheral blood mononuclear cells (PBMCs) of PD patients [24].

In our study population, high concentration of plasmatic $\alpha$-synuclein was found in PD patients, confirming previous results [54-56]. We did not observe a relation between $\alpha$-synuclein concentration and HSV-1-specific antibody in our patients, possibly because of the limited dimension of the study population, other studies in ampler cohorts are needed to verify if a direct association exists between these two parameters.

PD patients were also characterized by having a higher frequency of the PILRA rs1859788 minor allele A (AA + AG), this effect was even more evident when data were analyzed using sex as a variable. The presence of A allele causes the Glycin-to-Arginin substitution at 78 aa (G78R) of PILRA protein. If on the one hand this substitution seems to decrease HSV-1 infectivity [43], as the virus usually binds PILRA to enter cells [44], on the other hand the PILRA G/A substitution was suggested to interfere with the ability of PILRA to reduce microglial activation via PILRB/DA12 signaling [40,41,43,57]. PILRA regulates not only microglia and monocytes or macrophages [34], but also other immune cells, as neutrophils [40], it is thus tempting to speculate that an increased presence of PILRA G78R variant in PD patients could explain the increase inflammation status of these patients, and, in particular, the autoimmunity features that characterize the disease. Shedding light on the possible interactions between the humoral immune response against HSV-1 and other common pathogens and the genetics in PD could help understanding the possible impact of infections on disease onset and progression.

\section{Conclusions}

In conclusion, although preliminary and needing confirmation in bigger cohorts of patients, results herein could support a possible involvement of HSV-1 in Parkinson's disease, and may suggest that polymorphisms of the PILRA gene-a gene involved in HSV-1 infection-play a role in the neuroinflammation that accompanies this disease. The nature of HSV-1-specific immune responses will also need to be investigated in more depth in PD patients. In particular, the characterization of IgG subclasses and of the neutralizing activity of HSV-1-specific antibodies will need to be analyzed in PD to better understand the presence of possible interactions between HSV-1 infection and the disease. 
Author Contributions: Conceptualization, S.A., R.M., and M.C.; funding acquisition: M.C.; investigation, S.A., R.M., and F.R.G.; methodology, S.A., A.S.C., L.A.C., and M.M.; supervision, M.C.; visualization, S.A., J.N., and R.M.; writing-original draft, S.A. and R.M.; writing-review and editing, S.A., R.M., A.S.C., L.A.C., F.R.G., M.M., J.N., and M.C. All authors have read and agreed to the published version of the manuscript.

Funding: This research was supported by 2019-2021 Ricerca Corrente (Italian Ministry of Health).

Institutional Review Board Statement: The study was conducted according to the guidelines of the Declaration of Helsinki and approved by Ethics Committee of IRCCS Fondazione Don Gnocchi (\#06_21/06/2018).

Informed Consent Statement: Written informed consent was obtained from all subjects involved in the study.

Data Availability Statement: The data presented in this study are available on request from the corresponding author.

Acknowledgments: The authors thank all the subjects enrolled in the study; we are particularly grateful to all the nurses and MD of IRCCS Fondazione Don Gnocchi for taking care of the patients.

Conflicts of Interest: The authors declare no conflict of interest.

\section{References}

1. Simon, D.K.; Tanner, C.M.; Brundin, P. Parkinson disease epidemiology, pathology, genetics, and pathophysiology. Clin. Geriatr. Med. 2020, 36, 1-12. [CrossRef]

2. Pfeiffer, R.F. Non-motor symptoms in Parkinson's disease. Parkinsonism Relat. Disord. 2016, 22, S119-S122. [CrossRef]

3. Nussbaum, R.L.; Ellis, C.E. Alzheimer's disease and Parkinson's disease. N. Engl. J. Med. 2003, 348, 1356-1364. [CrossRef]

4. Emamzadeh, F.N.; Surguchov, A. Parkinson's disease: Biomarkers, treatment, and risk factors. Front. Neurosci. 2018, 12, 612. [CrossRef] [PubMed]

5. Du, X.Y.; Xie, X.X.; Liu, R.T. The role of $\alpha$-Synuclein oligomers in Parkinson's disease. Int. J. Mol. Sci. 2020, 21, 8645. [CrossRef]

6. Gelders, G.; Baekelandt, V.; Van der Perren, A. Linking neuroinflammation and neurodegeneration in Parkinson's disease. J. Immunol. Res. 2018, 2018, 4784268. [CrossRef] [PubMed]

7. Piancone, F.; Saresella, M.; La Rosa, F.; Marventano, I.; Meloni, M.; Navarro, J.; Clerici, M. Inflammatory responses to monomeric and aggregated $\alpha$-synuclein in peripheral blood of Parkinon's disease patients. Front. Neurosci. 2021, 15, 639646. [CrossRef]

8. Olsen, L.K.; Dowd, E.; McKernan, D.P. A role for viral infections in Parkinson's etiology? Neuronal. Signal. 2018, 2. [CrossRef] [PubMed]

9. Elizan, T.S.; Madden, D.L.; Noble, G.R.; Herrmann, K.L.; Gardner, J.; Schwartz, J.; Smith, H., Jr.; Sever, J.L.; Yahr, M.D. Viral antibodies in serum and CSF of Parkinsonian patients and controls. Arch. Neurol. 1979, 36, 529-534. [CrossRef] [PubMed]

10. Wu, W.Y.Y.; Kang, K.H.; Chen, S.L.S.; Chiu, S.Y.H.; Yen, A.M.F.; Fann, J.C.Y.; Su, C.W.; Liu, H.C.; Fu, W.M.; Chen, H.H.; et al. Hepatitis C virus infection: A risk factor for Parkinson's disease. J. Viral. Hepatol. 2015, 22, 784-791. [CrossRef] [PubMed]

11. Sa, A.C.C.; Madsen, H.; Brown, J.R. Shared molecular signatures across neurodegenerative diseases and herpes virus infections highlights potential mechanisms for maladaptive innate immune responses. Sci. Rep. 2019, 9, 8795.

12. Von Economo, C. Die Encephalitis Lethargica, ihre Nachkrankheiten und ihren Behandlung; Urban \& Schwarzenberg: Vienna, Austria, 1929; pp. 394-474.

13. Jang, H.; Bolz, D.; Strum-Ramirez, K.; Shepher, K.R.; Jiao, Y.; Webster, R.; Smeyne, R.J. Highly pathogenic H5N1 influenza virus can enter the central nervous system and induce neuroinflammation and neurodegeneration. Proc. Natl. Acad. Sci. USA 2009, 106, 14063-14068. [CrossRef] [PubMed]

14. Marttila, R.; Arstila, P.; Nikoskelainen, J.; Halonen, P.; Rinne, U. Viral antibodies in the sera from patients with Parkinson disease. Eur. Neurol. 1977, 15, 25-33. [CrossRef] [PubMed]

15. Marttila, R.J.; Rinne, U.K. Herpes simplex virus antibodies in patients with Parkinson's disease. J. Neurol. Sci. 1978, 35, 375-379. [CrossRef]

16. Marttila, R.J.; Rinne, U.K.; Halonen, P.; Madden, D.L.; Sever, J.L. Herpes viruses and Parkinsonism: Herpes simplex virus types 1 and 2, and cytomegalovirus antibodies in serum and CSF. Arch. Neurol. 1981, 38, 19-21. [CrossRef]

17. Marttila, R.J.; Rinne, U.K.; Tiilikainen, A. Virus antibodies in Parkinson's disease: Herpes simplex and measles virus antibodies in serum and CSF and their relation to HLA types. J. Neurol. Sci. 1982, 54, 227-238. [CrossRef]

18. Bu, X.L.; Yao, X.Q.; Jiao, S.S.; Zeng, F.; Liu, Y.H.; Xiang, Y.; Liang, C.R.; Wang, Q.H.; Wang, X.; Cao, H.Y.; et al. A study on the association between infectious burden and Alzheimer's disease. Eur. J. Neurol. 2015, 22, 1519-1525. [CrossRef] [PubMed]

19. Harris, M.A.; Tsui, J.K.; Marion, S.A.; Shen, H.; Teschke, K. Association of Parkinson's disease with infections and occupational exposure to possible vectors. Mov. Disord. 2012, 27, 1111-1117. [CrossRef] [PubMed]

20. Fatahzadeh, M.; Schwartz, R.A. Human herpes simplex virus infections: Epidemiology, pathogenesis, symptomatology, diagnosis, and management. J. Am. Acad. Dermatol. 2007, 57, 737-763. [CrossRef] 
21. Nicoll, M.P.; Proenca, J.T.; Efstathiou, S. The molecular basis of herpes simplex virus latency. FEMS. Microbiol. Rev. 2012, 26, 684-705. [CrossRef] [PubMed]

22. World Health Organizaton. Herpes Simplex Virus. 2020. Available online: http://www.who.int/mediacentre/factsheets / fs400 / en / (accessed on 1 June 2021).

23. Caggiu, E.; Paulus, K.; Arru, G.; Piredda, R.; Sechi, G.P.; Sechi, A. Humoral cross reactivity between a-synuclein and herpes simplex-1 epitope in Parkinson's disease, a triggering role in the disease? J. Neuroloimmunol. 2016, 291, 110-114. [CrossRef]

24. Caggiu, E.; Paulus, K.; Galleri, G.; Arru, G.; Manetti, R.; Sechi, G.P.; Sechi, L.A. Homologous HSV1 and alpha-synuclein peptides stimulate a T cell response in Parkinson's disease. J. Neuroimmunol. 2017, 310, 26-31. [CrossRef] [PubMed]

25. La Rosa, F.; Agostini, S.; Bianchi, A.; Nemni, R.; Piancone, F.; Marventano, I.; Mancuso, R.; Saresella, M.; Clerici, M. Herpes simplex virus-1 (HSV-1) infection induces a potent but ineffective IFN-1 production in immune cells of AD and PD patients. J. Trans. Med. 2019, 17, 286. [CrossRef] [PubMed]

26. Hawkes, C.H.; Del Tredici, K.; Braak, H. Parkinson's disease: The dual hit theory reviseted. Ann. N. Y. Acad. Sci. 2009, 1170, 615-622. [CrossRef]

27. Mori, I. Herpes simplex virus type 1 in the aged brain through hypothetical expression of accessory genes. J. Neurovirol. 2010, 16, 203-207. [CrossRef] [PubMed]

28. Mori, I. Viremic attack explains the dual-hit theory of Parkinon's disease. Med. Hypothesis 2017, 101, 33-36. [CrossRef] [PubMed]

29. Kobayashi, N.; Nagata, T.; Shinagawa, S.; Oka, N.; Shimada, K.; Shimizu, A.; Tatebayashi, Y.; Yamada, H.; Nakayama, K.; Kondo, $\mathrm{K}$. Increase in the IgG avidity index due to herpes simplex virus type 1 reactivation and its relationship with cognitive function in amnestic mild cognitive impairment and Alzheimer's disease. Biochem. Biophys. Res. Commun. 2013, 840, 907-911. [CrossRef] [PubMed]

30. Mancuso, R.; Baglio, F.; Cabinio, M.; Calabrese, E.; Hernis, A.; Nemni, R.; Clerici, M. Titers of herpes simplex virus type 1 antibodies positively correlate with grey matter volumes in Alzheimer's disease. J. Alzheimers Dis. 2014, 33, 741-745. [CrossRef]

31. Agostini, S.; Mancuso, R.; Baglio, F.; Cabinio, M.; Hernis, A.; Costa, A.S.; Calabrese, E.; Nemni, R.; Clerici, M. High avidity HSV-1 antibodies correlate with absence of amnestic Mild Cognitive Impairment conversion to Alzheimer's disease. Brain Behav. Immun. 2016, 58, 254-260. [CrossRef]

32. Mancuso, R.; Cabinio, M.; Agostini, S.; Baglio, F.; Clerici, M. HSV-1 specific IgG3 titers correlate with brain cortical thinning in individuals with Mild Cognitive Impairment and Alzheimer's disease. Vaccines 2020, 8, 255. [CrossRef]

33. Wozniak, M.A.; Itzhaki, R.F.; Shipley, S.J.; Dobson, C.B. Herpes simplex virus infection causes cellular $\beta$-amyloid accumulation and secretase upregulation. Neurosci. Lett. 2007, 429, 95-100. [CrossRef]

34. Alvarez, G.; Aldudo, J.; Alonso, M.; Santana, S.; Valdivieso, F. Herpes simplex virus type 1 induces nuclear accumulation of hyperphosphorylated tau in neuronal cells. J. Neurosci. Res. 2012, 90, 1020-1029. [CrossRef]

35. De Chiara, G.; Piacentini, R.; Fabiani, M.; Mastrodonato, A.; Marcocci, M.E.; Limongi, D.; Napoletani, G.; Protto, V.; Coluccio, P.; Celestino, I.; et al. Recurrent herpes simplex virus-1 infection induces hallmarks of neurodegeneration and cognitive deficits in mice. PLoS Pathog. 2019, 15, e1007617. [CrossRef] [PubMed]

36. Santana, S.; Bullido, M.J.; Recuero, M.; Valdivieso, F.; Aldudo, J. Herpes simplex virus type I induces an incomplete autophagic response in human neuroblatoma cells. J. Alzheimer's Dis. 2012, 30, 815-831. [CrossRef]

37. Wang, W.Z.; Fang, X.H.; Cheng, X.M.; Jiang, D.H.; Lin, Z.J. A case-control study on the environmental risk factors of Parkinsons's Disease in Tianjin, China. Neuroepidemiology 1993, 12, 209-218. [CrossRef]

38. Bu, X.L.; Wang, X.; Xiang, Y.; Shen, L.L.; Wang, Q.H.; Liu, Y.H.; Jiao, S.S.; Wang, Y.R.; Cao, H.Y.; Yi, X.; et al. The association between infectious burden and Parkinson's disease: A case-control study. Parkinsonsism Relat. Disord. 2015, 12, 877-881. [CrossRef]

39. Cury, R.G.; Lopez, W.O. Bilateral striatal lesion due to herpesvirus-6 infection. J. Neurol. Sci. 2015, 358, 538-539. [CrossRef] [PubMed]

40. Wang, J.; Shiratori, I.; Uehori, J.; Ikawa, M.; Arase, H. Neutrophil infiltration during inflammation is regulated by PILRA via modulation of integrin activation. Nat. Immunol. 2014, 2, 860-870.

41. Kohyama, M.; Matsuoka, S.; Shida, K.; Sugihara, F.; Aoshi, T.; Kishida, K.; Ishii, K.J.; Arase, H. Monocyte infiltration into obese and fibrilized tissues is regulated by PILR $\alpha$. Eur. J. Immunol. 2014, 46, 1214-1223. [CrossRef] [PubMed]

42. Lambert, J.C.; Ibrahim-Verbaas, C.A.; Harold, D.; Naj, A.C.; Sims, R.; Bellenguez, C.; DeStafano, A.L.; Bis, J.C.; Beecham, G.W.; Grenier-Boley, B.; et al. Meta-analysis of 74,046 individuals identifies 11 new susceptibility loci for Alzheimer's disease. Nat. Gen. 2013, 45, 1452-1458. [CrossRef]

43. Rathore, N.; Ramani, S.R.; Pantua, H.; Payandeh, J.; Bhangale, T.; Wuster, A.; Kapoor, M.; Sun, Y.; Kapadia, S.B.; Gonzales, L.; et al. Paired immunoglobulin-like type 2 receptos alpha G78R variant alters ligand binding and confers protection to Alzheimer's disease. PLoS Genet. 2018, 14, e1007427. [CrossRef]

44. Satoh, T.; Arii, J.; Suenaga, T.; Wang, J.; Kogure, A.; Uehori, J.; Arase, N.; Shiratori, I.; Tanaka, S.; Kawaguchi, Y.; et al. PILR $\alpha$ is a herpes simplex virus-1 entry co-receptors that associated with glycoprotein B. Cell 2008, 132, 935-944. [CrossRef]

45. Agostini, S.; Costa, A.S.; Mancuso, R.; Guerini, F.R.; Nemni, R.; Clerici, M. The PILRA G78R variant correlated with higher HSV-1 specific IgG titers in Alzheimer's disease. Cell. Mol. Neurobiol. 2019, 39, 1217-1221. [CrossRef]

46. Postuma, R.B.; Berg, D.; Stern, M.; Powe, W.; Olanow, C.W.; Oertel, W.; Obeso, J.; Marek, K.; Litvan, I.; Lang, A.E.; et al. MDS clinical diagostic criteria for Parkinson's disease. Mov. Disord. 2015, 30, 1591-1601. [CrossRef] [PubMed] 
47. Goetz, C.G.; Tilley, B.C.; Shaftman, S.R.; Stebbins, G.T.; Fahn, S.; Martinez-Martin, P.; Poewe, W.; Sampaio, C.; Stern, M.B.; Dodel, R.; et al. Movement disorder society-sponsored revision of the unified Parkinson's disease rating scale (MDS-UPDRS): Scale presentation and clinimetric testing results. Mov. Disord. 2008, 23, 2129-2170. [CrossRef] [PubMed]

48. Tomilson, C.L.; Stowe, R.; Patel, S.; Rick, C.; Gay, R.; Clarke, C.E. Systematic review of Levodopa dose equivalency reporting in Parkinson's disease. Mov. Disord. 2010, 25, 2649-2653.

49. Yuan, H.; You, J.; You, H.; Zheng, C. Herpes Simplex Virus 1 UL36USP antagonizes type I interferon-mediated antiviral innate immunity. J. Virol. 2018, 92. [CrossRef]

50. De Virgilio, A.; Greco, A.; Fabbrini, G.; Inghilleri, M.; Rizzo, M.I.; Gallo, A.; Conte, M.; Rosato, C.; Ciniglio Appiani, M.; de Vincentiis, M. Parkinson's disease: Autoimmunity and neuroinflammation. Autoimmun. Rev. 2016, 15, 1005-1011. [CrossRef]

51. Garretti, F.; Agalliu, D.; Lindestam Arlehamn, C.S.; Sette, A.; Sulzer, D. Autoimmunity in Parkinson's disease: The role of $\alpha$-synuclein-specific T cells. Front. Immunol. 2019, 10, 303. [CrossRef]

52. Mahdavi, T. Inflammation in Parkinson's disease. In Scientific and Clinical Aspects; Thomas, M., Ed.; Springer International Publishing: Cham, Switzerland, 2014; pp. 105-126.

53. Sulzer, D.; Alcalay, R.N.; Garretti, F.; Cote, L.; Kanter, E.; Agin-Liebes, J.; Liong, C.; McMurtrey, C.; Hildebrand, W.H.; Mao, X.; et al. T cells from patients with Parkinson's disease recognize $\alpha$-synuclein peptides. Nature 2017, 546, 656-661. [CrossRef]

54. Bougea, A.; Stefai, L.; Paraskeva, G.P.; Emmanouilidou, E.; Vekrelis, K.; Kapaki, E. Plasma alpha-synucelin levels in patients with Parkinson's disease: A systematic review and meta-analysis. Neurol. Sci. 2019, 40, 929-938. [CrossRef] [PubMed]

55. Chang, C.W.; Yang, S.Y.; Yang, C.C.; Chang, C.W.; Wu, Y.R. Plasma and serum alpha-synuclein as a biomarker of diagnosis in patients with Parkinson's disease. Front. Neurol. 2019, 10, 1388. [CrossRef] [PubMed]

56. Agliardi, C.; Meloni, M.; Guerini, F.R.; Zanzottera, M.; Bolognesi, E.; Baglio, F.; Clerici, M. Oligomeric $\alpha$-Syn and SNARE complex proteins in peripheral extracellular vesicles of neural origin are biomarkers for Parkinson's disease. Neurobiol. Dis. 2021, 148, 105185. [CrossRef] [PubMed]

57. Mousseau, D.D.; Banville, D.; L'Abbe, D.; Bouchard, P.; Shen, S.H. PILR $\alpha$, a novel immunoreceptor tyrosine-based inhibitory motif-bearing protein, recruits SHP-1 upon tyrosine phosphorylation and is paired with the truncated counterpart PILRb. J. Biol. Chem. 2000, 275, 4467-4474. [CrossRef] [PubMed] 